MICHAt NIEBYLSKI

Uniwersytet Opolski

\title{
Myśl komunitariańska w perspektywie debaty nad formułą społeczeństwa obywatelskiego
}

Dosługiwanie się terminem „społeczeństwo obywatelskie” obciążone jest poważnym i trudnym do zignorowania ryzykiem. Zwłaszcza w takim kraju jak Polska, gdzie termin ten stał się popularny stosunkowo niedawno. Jeśli wziąć pod uwagę praktykę życia politycznego i projektowane zmiany ustrojowe, wówczas trzeba powiedzieć, że ożywione zainteresowanie ideą społeczeństwa obywatelskiego rozpoczęło się wraz z budową porządku III RP. Natomiast, jeśli skupimy się na polskiej myśli społecznej oraz wysuwanych przez opozycyjnych intelektualistów postulatach utworzenia autonomii społecznej gwarantowanej zarówno przez instytucjonalną przestrzeń dyskursowej interakcji, jak i wolne stowarzyszenia, wówczas można śmiało bronić tezy, iż idea społeczeństwa obywatelskiego miała w Polsce wielu zwolenników jeszcze przed demontażem systemu komunistycznego. Otóż, tak krótki żywot tego pojęcia w polskiej praktyce i teorii politycznej, a zarazem gwałtowna intensywność jego pojawiania się niemal przy każdej dyskusji dotyczącej porządku społecznego, budzi uzasadnioną wątpliwość, czy używany przez nas słownik polityczny uchwycił to pojęcie wraz z całym jego bagażem historycznym? Powiedzieć o terminie „społeczeństwo obywatelskie”, że jest obciążone historycznie, to powiedzieć, że ani politycznie, ani ideologicznie nie da się 
go jednoznacznie dookreślić, albowiem jego związki z różnymi tradycjami wykluczają taką kwalifikację ${ }^{1}$.

Obserwując historyczny rozwój tego pojęcia, śledząc proces jego dojrzewania do obecnego znaczenia, trudno nie odnieść wrażenia, że uległ daleko idącej modyfikacji. Ewolucja tego pojęcia (podobnie jak kategoria obywatela) oznaczała stałe poszerzanie jego ładunku semantycznego i była sprzężona z utratą pierwotnych konotacji. Symplifikując, można powiedzieć, że społeczeństwo obywatelskie ma korzenie zarówno republikańskie, jak i liberalne.

W optyce republikańskiej społeczeństwo obywatelskie jest definiowane jako wspólnota polityczna, której członkowie są powołani do aktywności politycznej, która rozwija ich zdolności i podnosi ich status. U Arystotelesa występowała jako koinonia politike, zaś u Cycerona jako societas civilis. Wspólnym dla nich mianownikiem jest ontologiczna prymarność wspólnoty nad jej członkami, co uzasadnia podporządkowanie prywatnego ,ja” domenie tego, co publiczne. Klasyczne ujęcie opiera się na esencjalistycznym i teleologicznym rozumieniu obywatela pojmowanego jako polites, którego natura uczyniła członkiem wspólnoty - i co za tym idzie wyznaczyła mu określone zadania, a ich wypełnienie implikuje zrealizowanie jego istoty. Najwyższym powołaniem człowieka, według Stagiryty, była partycypacja w kolektywnym podejmowaniu decyzji, albowiem w ten sposób obywatel artykułował swoją wolność pojmowaną w kategoriach używając dychotomii Izajasza Berlina - pozytywnych, a także miał udział w trosce o dobro wspólne. Jednostka wyłączona ze spraw zbiorowości lub alienująca się od nich ulegała, według Arystotelesowskiej wykładni, degradacji moralnej i duchowej ${ }^{2}$. Natomiast to, co prywatne, czyli sprawy gospodarstwa domowego (oikos), nie leżało w granicach sfery obywatelskiej bądź to dlatego, że w powszechnym odczuciu działalność o charakterze gospodarczym nie licowała z godnością obywatela, a sukcesy w tej sferze nie wystawiały świadectwa posiania cnót, jakie ceniono w antycznym świecie ${ }^{3}$, bądź też dlatego, że obie sfery były od siebie tak dalece odseparowane, że powodzenie w sferze prywatnej nie przekładało się na poprawę kondycji polis, jak chcieliby nowożytni teoretycy.

Człowiek w starożytnym świecie nie należał do siebie, lecz do wspólnoty - tak samo jak w wykładni chrześcijańskiej człowiek należał do

J. Szacki, Wstęp. Powrót idei spoleczeństwa obywatelskiego, [w:] Ani książę, ani kupiec: obywatel, wybór tekstów, J. Szacki, Wyd. Znak, Kraków 1997, s. 62.

Arystoteles, Polityka, przeł. L. Piotrowicz, Wyd. im. Ossolińskich, Wrocław 2005, s. 45.

H. Arendt, Kondycja ludzka, przeł. A. Łagodzka, Fundacja Aletheia, Warszawa 2000, s. 36. 
Boga - toteż sprawy publiczne monopolizowały uwagę obywateli i w ich hierarchii wartości znajdowały się na pierwszym miejscu ${ }^{4}$. Tak skonceptualizowana koinonia politike nadawała substancjalną treść formule obywatelstwa, która kojarzyła się ze służbą publiczną i cnotami obywatelskimi oraz miała charakter tyleż elitarny, co ekskluzywny, mimo wielu prób, jeśli można tak powiedzieć, „liberalizowania” zasad przyznawania statusu obywatela, podjętych najpierw przez Solona, później przez Klejstenesa i wreszcie przez Peryklesa. Kategoria obywatelstwa zarówno u Arystotelesa, jak i Cycerona nie akcentowała uprawnień jednostek, tak jak dzieje się to w teorii liberalnej, lecz ustawiała wektor w przeciwnym kierunku; wspólnota polityczna była wartością autoteliczną i to ona koncentrowała na sobie uwagę obywateli, a nie odwrotnie.

Tradycja republikańska wywodząca się explicite od Arystotelesa, rozwijana później przez Cycerona oraz innych rzymskich historyków, uzyskała pełniejszy wymiar u średniowiecznych arystotelików, zwłaszcza u św. Tomasza z Akwinu, a następnie zdołała się zaadaptować w republikach włoskich, w szczególności w Wenecji, Florencji oraz Padwie i tam promieniować na rozwój myśli średniowiecznej i renesansowej na temat społeczeństwa obywatelskiego, co zaowocowało teoriami Marsyliusza z Padwy czy Niccolo Machiavelliego ${ }^{5}$.

$\mathrm{Na}$ gruncie liberalizmu kategoria społeczeństwa obywatelskiego uległa znaczącej redefinicji po części dlatego, że wymagała tego zmieniająca się sfera społeczna, która podlegając procesom transformacyjnym przechodziła z ustroju feudalnego w ustrój kapitalistyczny ${ }^{6}$, po części zaś dlatego, że tradycja wywodząca się od Johna Locke’a była immanentnie związana z oświeceniem, którego sens, jak sądzę, najlepiej wyraża konstatacja Thomasa Paine'a: „czas rozstać się”. Z czym? Ze wszystkim co nie posiada potwierdzenia $\mathrm{w}$ rozumie! Tak jak Nietzsche próbował w dziewiętnastym wieku wyrugować historię z życia za jej szkodliwe oddziaływanie na teraźniejszość, tak apologeci oświecenia i będący w jego orbicie wpływów prekursorzy tradycji wolnościowej, próbowali za jednym zamachem odrzucić przeszłość i wszelkie tradycje krępujące, w ich opinii, wyobraźnię i wolność człowieka. Gdyby nie oświecenie i towarzyszące tej epoce optymizm i wiara w nieograniczoną i kumulatywną potęgę wiedzy,

M. Środa, Indywidualizm i jego krytycy: wspótczesne spory między liberałami, komunitarianami i feministkami na temat podmiotu, wspólnoty i płci, Fundacja Aletheia, Warszawa 2003, s. 69 .

D. Pietrzyk-Reeves, Idea społeczeństwa obywatelskiego. Wspótczesna debata ijej źródła, Wyd. Uniwersytetu Wrocławskiego, Wrocław 2004, s. 28.

Ibidem, s. 58 . 
najpełniej zamanifestowane przez francuskich filozofów, najpierw przez Anne Roberta Turgota, a prawie pół wieku później przez Jeana Condorceta, nie byłoby ani rewolucji francuskiej, ani tym bardziej aplikacji konstytucji w amerykański krwiobieg polityczny w czasie, gdy Bastylia i ancien régime dopiero zaczynały chwiać się w posadach.

Liberalny dyskurs o społeczeństwie obywatelskim zerwał z archetypicznym ujęciem tego terminu i wprowadził doń nowe treści filozoficzne i ideologiczne. Funkcjonalistyczna redukcja społeczeństwa obywatelskiego do wymogów i oczekiwań sfery społecznej penetrowanej przez kapitalizm oraz ideologiczne korelaty tego systemu, polegała na odrzuceniu esencjalistycznych i teleologicznych presumpcji dotyczących natury obywatela i - co za tym idzie - zastąpieniu greckiego polites i rzymskiego citoyen nowożytnym konstruktem, jakim jest burgeois. Obywatel w sensie nowożytnym jest mieszczaninem, jednostką, która pod względem ontologicznym wyprzedza pojawienie się zarówno społeczeństwa, jak i państwa, a przez to jest założycielem ich obu, jak dzieje się to na mocy umowy społecznej u Tomasza Hobbesa i Johna Locke'a. Przyjęcie teorii kontraktualistycznej miało nie tyle wyjaśnić pojawienie się bytów ponadjednostkowych, co przede wszystkim uzasadnić wyprowadzenie określonych reguł życia społecznego, których celem było zabezpieczenie jednostki i jej uprawnień pojmowanych na sposób negatywny, przed państwem i społeczeństwem. Eksplikując motywy powstania państwa na bazie teorii liberalnych, trzeba wskazać na motywację stricte utylitarystyczną, wedle której, jednostki organizują ramy instytucjonalne po to, aby zakończyć przedspołeczny stan bellum omnia contra omnes, jak dzieje się to u Hobbe$\mathrm{sa}^{7}$, albo ze względu na korzyść, jaką jest ochrona zdrowia, wolności i własności, jak chciał tego Locke w Dwóch traktatach o rządzie ${ }^{8}$.

Taka konceptualizacja lokuje jednostkę w opozycji zarówno do społeczeństwa, jak i państwa, nadając jej podmiotową autonomiczność, a jej interesy traktując w oderwaniu od społecznych i moralnych obligacji. Relacje jednostki ze środowiskiem społecznym nie są podporządkowane żadnej organicznej konieczności, jak działo się to u starożytnych Greków, lecz tylko decyduje o tym wola jednostki. Według republikańskiej wykładni obywatel w znaczeniu burgeois, afirmowany przez tradycję liberalną, byłby raczej odpowiednikiem greckiego idiotes aniżeli transmutacją citoyen. Nie definiuje go bowiem partycypacja w sferze publicznej ani cnota

Zob. T. Hobbes, Lewiatan, czyli materia, forma i władza państwa kościelnego i świeckiego, przeł. Cz. Znamierowski, Fundacja Aletheia, Warszawa 2005.

8 Zob. J. Locke, Dwa traktaty o rzadzie, przeł. A. Czarnota, PWN, Warszawa 1992. 
i sprawności obywatelskie, a dzieje się tak nie tylko dlatego, że nie ma substancjalnych kryteriów, a tylko formalne, ale przede wszystkim dlatego, że cnota obywatelska przestaje być funkcjonalną kategorią dla liberalnej myśli politycznej, a w jej miejsce wprowadza się dobrze pojęty interes własny.

Teoria liberalna, ilekroć opowiadała się za indywidualistycznym poglądem na jednostkę, tylekroć akcentowała fakt, iż jest ona wyposażona w wolność zdefiniowaną na sposób negatywny, głoszoną już od czasów Locke'a, a następnie rozwijaną przez Johna Stuarta Milla i kontynuowaną przez filozofów współczesnych takich jak: Izajasz Berlin i Karl Popper, co w porównaniu do wolności politycznej Arystotelesa czy Cycerona, oznacza ni mniej ni więcej rewolucję semantyczną. Ilustrację różnicy między nimi można odszukać w poglądach Benjamina Constanta, dla którego wolność nowożytna nie polegała na permanentnej dyspozycji do uczestnictwa w zbiorowej władzy, lecz tylko na czerpaniu korzyści z gwarantowanej przez instytucje władzy publicznej niezależności prywatnej".

O ile w tradycji wywodzącej się od Arystotelesa koinonia politike miała potencjał normatywny, a więc określała pożądany model interakcji społecznych i wiązała życie we wspólnocie z doskonaleniem etycznym i poznawczym, o tyle model społeczeństwa obywatelskiego, za jakim optuje część liberalnych teoretyków, nie zawiera tych aspektów. Od czasów Locke'a, poprzez Adama Smitha, aż po Hegla pojemność konotatywna społeczeństwa obywatelskiego ciągle zwiększała się, przy jednoczesnym kurczeniu się w niej zasobów republikańskich. Postawienie na głowie antropologii Arystotelesowskiej nie wyczerpało zapału reformatorskiego tradycji liberalnej, albowiem dokonała również ogromnych przeobrażeń w samej konceptualizacji społeczeństwa obywatelskiego, które nie jest już tożsame ze społeczeństwem politycznym, a między nim a państwem wprowadza się wyraźny dystans na przekór adwersarzom o republikańskim rysie tego autoramentu, co Tomasz z Akwinu czy Jean Bodin. Słowem: liberalna myśl polityczna autonomizuje obie sfery, przypisując członkom społeczeństwa obywatelskiego kwalifikacje do prowadzenia działalności gospodarczej zgodnie z kapitalistycznym paradygmatem.

To, co w zamyśle liberałów miało doprowadzić do emancypacji społeczeństwa obywatelskiego spod kurateli państwa wygenerowało nieoczekiwany skutek w postaci alienacji polityki i doprowadziło do pogrążenia się obywateli w tym, co prywatne. Już antyczni Grecy rozumie-

B. Constant, O wolności starożytnych i nowożytnych, przeł. Z. Kosno, „Arka” 1992, nr 42, s. 77. 
li, że człowiek, który zamyka się tylko w prywatności, jest stracony dla życia obywatelskiego. Nawet w dyskursie liberalnym wykrystalizowała się narracja szkocka, reprezentowana między innymi przez Adama Fergusona, która tym różniła się od tradycji wolnościowej głównego nurtu, że zarejestrowała defekty związane ze skrajnie indywidualistycznym myśleniem o jednostce i lekceważącym traktowaniem sfery polityki. Jest to nie tyle skorygowana wersja liberalizmu, ile raczej podejście, jak sądzę, świadome strat związanych z implementacją liberalnych zasad w krwiobieg życia politycznego, toteż uważa za równie istotne troskę o byt materialny oraz rozwój cnót obywatelskich ${ }^{10}$. Mimo, iż Ferguson i inni przedstawiciele szkockiego oświecenia równie wysoko oceniali postęp jak pozostali admiratorzy liberalizmu, interpretując go jako nieprzerwany proces akumulacji wiedzy, umiejętności, a nawet doskonałości moralnej, to wyróżniał ich ciągle obecny w rozważaniach dysonans, czy w warunkach rozwoju handlu i ekonomizacji stosunków społecznych uda się utrzymać postawę charakterystyczną dla Arystotelesowskiego zoon politicon, czy może nastąpi regres kultury obywatelskiej i deprecjacja wartości politycznych. Dla Davida Hume'a kwestia ta nie budziła wątpliwości: inflacja znaczenia sprawności obywatelskich i obniżenie się standardów politycznych są nieuchronne i nie musimy nadawać tym zjawiskom pejoratywnego zabarwienia ${ }^{11}$.

Jedno wszak wydaje się oczywiste, im bardziej liberalna myśli polityczna kładła nacisk na rozwój stosunków interpersonalnych w przestrzeni społecznej, tym mniejsze zainteresowanie obywateli wzbudzała sfera polityki i tym większe spustoszenie powodowała dla kategorii dobra wspólnego. Zgodzić się należy z Pawłem Śpiewakiem, który skonstatował, iż „myślenie o polityce poprzez ideę dobra wspólnego jest obecne jedynie na marginesie czy w przypisach myśli politycznej. Ciekawe dla antykwariuszy historii idei, martwe dla aktualnej myśli politycznej" ${ }^{12}$. O ile w perspektywie republikańskiej kategoria dobra wspólnego miała charakter substancjalny, o tyle w optyce liberalnej uległa całkowitej erozji, co widać wyraźnie w poglądach Hume'a, który suponował, iż jedynym dobrem realnie istniejącym jest dobro partykularne i nie ma podstaw do przypusz-

10 Zob. więcej D. Pietrzyk-Reeves, Idea społeczeństwa obywatelskiego. Wspótczesna debata ijej źródła, op. cit., s. 69-81.

11 T. Tulejski, Konserwatyzm bez Boga: Dawida Hume'a wizja spoleczeństwa, państwa i prawa, Fijorr Publishing Company, Warszawa 2009, s. 52.

12 P. Śpiewak, W stronę wspólnego dobra, Fundacja Aletheia, Warszawa 1998, s. 5. 
czenia, by istniało dobro ogólne o zdolności transgresywnej, czyli takiej, która przekracza indywidualne różnice.

Liberalną filozofię państwa i społeczeństwa obywatelskiego można interpretować, z jednej strony, jako odpowiedź na doświadczenie centralizacji polityki w absolutystycznym lub rewolucyjnym wydaniu, $\mathrm{z}$ drugiej zaś, jako realizację interesów tworzącego się mieszczaństwa. I bynajmniej nie chodzi tylko o zabezpieczenie własności i stworzenie optymalnych warunków dla pomnażania kapitału, lecz także o konieczność wprowadzenia bezpieczeństwa prawnego i autonomii. Zasadne wydaje się więc pytanie, czy nowożytna koncepcja społeczeństwa obywatelskiego to nic innego, jak społeczeństwo burżuazyjne, na co wskazuje nie tylko jego niemiecka nazwa bürgerliche Gesellschaft, lecz również obfita literatura z zakresu filozofii politycznej, historii idei i socjologii? Dla Jürgena Kocka nie ulega wątpliwości, że program społeczeństwa obywatelskiego wyłonił się z dyskusji prowadzonych przez członków tworzącego się mieszczaństwa. Falsyfikacja owej tezy jest możliwa po uprzednim zwróceniu uwagi na fakt, iż otrzymanie całkowitych praw obywatelskich, posługując się przykładem Żydów w Niemczech, szło w parze z zasilaniem szeregów mieszczaństwa - i co za tym idzie - przyjmowaniem wzorców kulturowych, obyczajów i form towarzyskości ${ }^{13}$. Marks poszedł znacznie dalej synonimicznie rozumiejąc społeczeństwo obywatelskie i społeczeństwo burżuazyjne. Było dla niego sprawą oczywistą, iż oparcie takiego modelu społeczeństwa nie na citoyen, lecz na burgeois - a owa dystynkcja była kluczowa dla jego zabiegów ewaluacyjnych - miało za zadanie nadać realizacji partykularnych interesów, tendencjom wpisywania się w koniunkturę oraz ujawnieniu się wszelkich antagonizmów, priorytetowy charakter. Krytyczny opis społeczeństwa obywatelskiego dokonany przez Hegla, u Marksa został wyostrzony po to, aby mógł służyć urzeczywistnieniu projektu rewolucyjnego ${ }^{14}$.

Prezentacja ewolucji pojęcia społeczeństwa obywatelskiego w takiej postaci, obciążona jest, rzecz jasna, niedającą się zaakceptować skrótowością, a mimo to z aprobatą można przyjąć rezultat takiego zabiegu, jakim jest odtworzenie bogactwa idei, jakie kryje się za tym terminem, a które, jak się wydaje, zostało utracone, o czym przekonuje współczesna debata polityczna i filozoficzna poświęcona temu zagadnieniu, nie tylko zresztą

13 J. Kocka, O historii społecznej Niemiec, przeł. J. Kałążny, Wyd. Poznańskie, Poznań 1997, s. 53.

14 K. Marks, W kwestii żydowskiej, [w:] K. Marks, F. Engels, Dzieła, t. 1, Książka i Wiedza, Warszawa 1976, s. 431. 
w Polsce, lecz także w Europie Zachodniej. Szczególnie w naszym kraju, ilekroć konwersuje się na temat społeczeństwa obywatelskiego, tylekroć kontekstem tej deliberacji staje się ideologia liberalna i model demokracji przedstawicielskiej, tak jakby, po pierwsze, nie istniał alternatywny wariant dla funkcjonowania społeczeństwa obywatelskiego, po drugie zaś, nie dostrzegano lub celowo pomijano trudności w rozwoju społeczeństwa obywatelskiego właśnie z powodu ich niewłaściwego działania, czy też lepiej powiedzieć, ich wewnętrznych aberracji. Recepcja społeczeństwa obywatelskiego w polskiej myśli społecznej, a zwłaszcza w praktyce politycznej ogranicza się wyłącznie do jego nowożytnego ujęcia, pozostawiając na marginesie republikański wariant, uznawszy go za anachroniczny i nieadekwatny do wymogów bieżącej sytuacji społecznej, ekonomicznej i politycznej. Tym większa potrzeba przedstawienia i omówienia dorobku myśli komunitariańskiej, która rozwijała się w latach siedemdziesiątych i osiemdziesiątych minionego stulecia, wzbudzając gorącą dyskusję wokół aksjomatów proweniencji liberalnej.

Ogólnie rzecz biorąc, komunitarianizm za tendencje regresywne w obecnej kulturze świata zachodniego obarcza ideologię liberalizmu i afirmowane przez nią założenia na temat sfery społecznej i politycznej. Krytyka komunitariańska nie odnosi się, rzecz jasna, tylko do liberalizmu proceduralistycznego w wydaniu Johna Rawlsa (choć trzeba zaznaczyć, iż to właśnie Teoria sprawiedliwości tego autora obudziła i akcelerowała spór liberałów z komunitarianami), albowiem klasyczny liberalizm, wywodzący się od Johna Locke'a, Johna Stuarta Milla i Adama Smitha, zapoczątkował - można by powiedzieć - rewolucję kopernikańską w pojmowaniu jednostki, państwa, etyki i tym samym wskazał kierunek rozwoju dla myśli liberalnej w późniejszym okresie. Przypomnijmy, iż dzisiejsza teoria liberalna zaadaptowała od Locke'a przekonanie, że podstawową rolą i argumentem na rzecz istnienia państwa jest zabezpieczenie życia, wolności i własności obywateli. Od Immanuela Kanta liberalizm zapożyczył pojęcie autonomii (które jest obecne na przykład w koncepcjach Rawlsa ${ }^{15}$ ), dzięki której jednostka może teleologicznie projektować własne życie, włączając $\mathrm{w}$ to samodzielnie określenie systemu wartości. Inspiracje czerpane z filozofii Adama Smitha poskutkowały natomiast zakwalifikowaniem indywidualizmu moralnego do grona najważniejszych zasad, za jakimi opowiada się liberalizm. Za Millem liberalizm aprobował natomiast absolutyzowa-

\footnotetext{
15 R. Prostak, Rzecz o sprawiedliwości. Komunitarystyczna krytyka współczesnego liberalizmu amerykańskiego, Kraków 2004, s. 64.
} 
nie wolności i przeprowadzenie linii demarkacyjnej dla jej obowiązywania dopiero tam, gdzie zaczyna się wolność innej osoby ${ }^{16}$.

Filozofowie, którym bliska jest wrażliwość komunitariańska, uporczywie starają się dowodzić, jak bardzo szkodliwe są te idee i jak fatalne rezultaty przynosi ich obecność $\mathrm{w}$ dyskursie filozoficznym dla kondycji moralności we współczesnym świecie, jak bardzo zredukowały one tożsamość istot ludzkich oraz jak bardzo zaszkodziły one sprawie społeczeństwa obywatelskiego. Jeśli więc rzeczywistość społeczna jest kształtowana za pomocą idei proweniencji liberalnej, to dokonanie transformacji systemu społecznego nie może się powieść, bez wcześniejszego przełamania hegemoni ideologii liberalnej w przestrzeni filozoficznej i kulturowej. Prowadzi nas to do sedna komunitariańskiej wiary, która przewiduje, iż filozofia, wszelako dysponująca tylko ideami, musi ingerować przy ich użyciu w życie społeczne, musi walczyć o opracowanie nowego paradygmatu dla procesów stymulujących rozwój współczesnych społeczeństw. Innymi słowy: jej zadaniem jest nie tylko kontestacja obowiązującego układu politycznego i kulturowego, ale też zaproponowanie innej trajektorii myśli, a przede wszystkim wyznaczenie praktycznych reguł dla działań, mających na celu wprowadzenie na nowe tory praktykę społeczną i polityczną.

Narracja komunitariańska we współczesnym dyskursie filozoficznym, artykułowana przez intelektualistów tego autoramentu, co Alasdair MacIntyre, Charles Taylor, Michael Walzer czy Michael Sandel, nie wspominając już o Amitai'u Etzionim (choć niektórzy z nich polemizowaliby z taką klasyfikacją) wychodzą z założenia, iż liberalizm penetruje kulturę nowoczesnych społeczeństw tak głęboko, że tylko nieliczni potrafią zdobyć się na trud wyobrażenia sobie alternatywnego ładu. Nowoczesne społeczeństwa są zorientowane na zaspakajanie egoistycznych kaprysów, przywiązane są do liberalnych dogmatów, a jednocześnie nie wzruszają ich nakazy tradycji ani pouczenia autorytetów i religii. Są to realia spełnionego liberalnego marzenia ${ }^{17}$. Nie należy więc szukać sposobów na to, jak jeszcze umocnić pozycję liberalizmu we współczesnej kulturze Zachodu, lecz raczej, należy odpowiedzieć na pytanie: jakie koszty moralne i społeczne wiążą się z takim stanem? Zamiast petryfikować obecny porządek społeczny, trzeba pomyśleć nad jego znaczącą korektą, która uwzględniałaby nie tylko dobro wspólnoty, lecz także rolę tradycji, a nadto niezbędność innych formatywnych struktur, takich jak np. rodzi-

16 G. Himmelfarb, Jeden naród, dwie kultury, przeł. P. Bogucki, Wydawnictwa Akademickie i Profesjonalne, Warszawa 2007, s. 58.

17 A. MacIntyre, Dziedzictwo cnoty, przeł. A. Chmielewski, PWN, Warszawa 1997, s. 39. 
na. Dość - powiadają komunitarianie - gloryfikowania liberalizmu oraz lansowanego przez niego modelu społeczeństwa obywatelskiego. Pora przyjrzeć się im krytycznie. I komunitarianie, poprzez soczewkę republikańskiej, marksistowskiej, tomistycznej i konserwatywnej teorii robią to $\mathrm{z}$ wielką dokładnością, a rezultaty prowadzonego przez nich monitoringu są naprawdę imponujące, choć w pewnych punktach trudno zgodzić się $\mathrm{z}$ rezultatami ich dociekań filozoficznych.

Ewidentnym błędem nurtu wspólnotowego jest bowiem ufundowanie analizy stanu dzisiejszej kultury na założeniu, iż rzeczywistość społeczna i polityczna, w jakiej żyjemy, jest wypadkową wdrożenia w życie idei liberalnych. Rzeczywiście mamy do czynienia w przestrzeni społecznej z instytucjami, regułami i wartościami, które mają niewątpliwy związek z liberalizmem, nie znaczy to jednak, że żyjemy w warunkach w pełni zrealizowanego projektu, zapoczątkowanego przez Locke'a, Milla i kontynuowanego przez ich epigonów. Historia epoki nowoczesności albo jak chcą niektórzy postnowoczesności, nie jest pisana tylko przez admiratorów liberalizmu, lecz także przez zwolenników prądów antyliberalnych. Ich filozoficznego i politycznego znaczenia nie można lekceważyć.

Polemika komunitarian jest niezwykle obszerna, wielowątkowa i prowadzona bez mała na wszystkich istotnych płaszczyznach z punktu widzenia filozofii politycznej. Można jednak wyabstrahować z niej główne aspekty, w których niczym w soczewce będą koncentrowały się najważniejsze tezy i postulaty komunitarianizmu, a ich przydatność w dyskursie o formule społeczeństwa obywatelskiego nie będzie budziła najmniejszych zastrzeżeń. Osią sporu filozoficznego między nurtem wspólnotowym a liberalizmem jest nie tylko problem radykalnie odmiennego konceptualizowania jednostki i wspólnoty, ale również społeczeństwa obywatelskiego oraz roli państwa.

Zacznijmy od omówienia sposobu rozumienia wspólnoty przez komunitarian, albowiem od przyjęcia określonej definicji wspólnoty zależeć będzie charakterystyka jednostki. Pojemność konotatywna pojęcia „wspólnota” obejmuje zarówno wspólnoty sąsiedzkie, jak też wspólnoty lokalne i polityczne. Nie da się ich zdefiniować in abstracto, ponieważ w zależności od warunków historycznych albo charakteru kultury która je kształtuje, ich definicja musi wypaść rozmaicie. Można jedynie pokusić się o wyjaśnienie sensu samej wspólnotowości i podania okoliczności, w jakich występuje. Zdaniem Etzioniego warunkiem konstytucyjnym istnienia wspólnoty autentycznej, czyli takiej, która zachowuje równowagę między ładem społecznym a autonomią jednostki, jest obecność u jej członków afektywnych więzi zarówno o charakterze wertykalnym, jak 
i horyzontalnym, a oprócz tego identyfikacja ze wspólnym katalogiem aksjologicznym oraz stosunkowo wysoki poziom responsywności, czyli troski o społeczność ${ }^{18}$. W odróżnieniu od Etzioniego, Macintyre, Sandel i Taylor, uważają za najważniejsze dla trwałości wspólnoty nie więzi afektywne jej obywateli, nawet nie podzielanie przez nich przekonania na temat wspólnego dobra, które byłoby czymś więcej niż sumą indywidualnych preferencji, lecz przede wszystkim, narracyjne opisywanie świata społecznego, wspólny system komunikacji, praktyki społeczne, czyli mówiąc krótko, to wszystko, co współtworzy holistyczną przestrzeń sensu. Jest to taka wspólnota, która wyposaża swoich obywateli zarówno w odpowiednie narzędzia interpretacyjne za pomocą których dokonują oni ewaluacji rzeczywistości społecznej, jak również w określoną tożsamość społeczną, dzięki której, każdy obywatel czuje się wezwany do wyboru konkretnej aktywności życiowej, mając na uwadze potrzebę zrealizowania telosu.

Wypadkową tak pojmowanej wspólnoty jest zaadaptowanie, a następnie twórcze przeformułowanie antropologii Arystotelesa, wedle której, istota ludzka nie może funkcjonować poza obrębem wspólnoty; jest ona bowiem ex definione istotą społeczną i polityczną. Komunitarianie nie szczędzą słów krytyki liberalnym predylekcjom do redukowania bytu społecznego do mniej lub bardziej racjonalnych jednostek, do stawiania jej przed społecznością nie tylko pod względem ważności, ale też chronologii. Filozofia wszystkich wymienionych tu intelektualistów wspólnotowych sceptycznie odnosi się do liberalnej wiary w nieograniczone możliwości samodzielnego tworzenia przez jednostkę narracji na własny temat. Mimo, iż Walzer, Taylor i MacIntyre w różnych punktach lokują granice ludzkiej autonomii, zgadzając się na jej szeroki albo wąski zakres, to dla każdego z nich truizmem jest twierdzenie, że tożsamość ludzka jest wytworem wspólnoty, w której żyje. Innymi słowy: tożsamość jednostki jest zawsze społecznie konstruowana. Dla Taylora oznacza to zanurzenie indywidualnej jaźni w nieustającym dialogu ze znaczącymi Innymi, dla MacIntyre'a kontakt z tradycją kulturową i historyczną wspólnoty, natomiast dla Walzera po prostu promieniowanie społeczności na jednostkę - na jej wrażliwość społeczną, wyznawane poglądy i moralność. Jak przekonuje Taylor: „,moja tożsamość określona jest przez więzi i identyfikacje, stanowiące ramy lub horyzont, wewnątrz których mogę w każdym konkretnym przypadku próbować ustalić, co jest dobre czy wartościowe, co powinienem zrobić lub co popieram, a czemu się przeciwstawiam. In-

\footnotetext{
18 A. Etzioni, Wspólnota responsywna: perspektywa komunitariańska, [w:] Komunitarianie: wybór tekstów, oprac. P. Śpiewak, Fundacja Aletheia, Warszawa 2004, s. 190.
} 
nymi słowy, tylko wewnątrz tego horyzontu potrafię zająć jakiekolwiek stanowisko" ${ }^{19}$.

Program pozytywny komunitarianizmu, zakładający restytucję wspólnot, rzutuje na jego ewaluację współczesnych systemów demokratycznych. Zestawiając ze sobą tradycję liberalną i komunitariańską w kontekście problemu demokracji, należy zwrócić uwagę na ich silne umocowanie $\mathrm{w}$ odmiennych perspektywach ontologicznych, implikujących określone kryteria wartościujące, które z góry przesądzają o rezultatach w ocenie funkcjonowania systemów demokratycznych. O ile dla teorii liberalnej podstawowym kryterium weryfikacji działania demokracji jest to, czy w sposób efektywny i racjonalny potrafi rozwiązywać problemy społeczne i gospodarcze, a więc osadzone jest na płaszczyźnie stricte instrumentalnej, o tyle dla teorii komunitariańskiej kluczowym pytaniem jest to, czy potrafi ona zrealizować ideały o fundamentalnym znaczeniu w historycznym procesie jej formowania się. Pytanie, jakie zadają przedstawiciele nurtu wspólnotowego, w odróżnieniu od liberalnych adwersarzy, wyrasta z podłoża normatywnego, co każe zastanowić się, jak wypada demokracja w liberalnym wydaniu, w ocenie komunitarian, którzy probierzem właściwego funkcjonowania procesów politycznych w obrębie ustroju demokratycznego nie czynią zgodności z regułami, jakie afirmuje rozum instrumentalny.

Mówiąc o nim mam na myśli, idąc za Taylorem, ten rodzaj racjonalności, którym posługujemy się, aby „wyliczyć najbardziej ekonomiczny sposób wykorzystania środków prowadzących do danego celu" ${ }^{20}$. Z punktu widzenia efektywności określone działanie jest znaczące o tyle, o ile da się je ocenić według kryteriów instrumentalnych. To zaś, co nie poddaje się kalkulacji, co jest niewrażliwe na postulat maksymalizacji wydajności jest spychane na margines przeżytku i dogmatu.

Władza demokratyczna, jak suponuje Taylor, autonomizuje się od mechanizmów społecznej kontroli, a przez to rośnie dystans między rządzącymi a rządzonymi do tego stopnia, że nie sposób udawać, że go nie ma ani przeoczyć konsekwencji, jakie rodzi. Wzajemne interakcje między nimi stopniowo zanikają, a w ich miejscu krystalizuje się nowy układ polityczny, w którym władza jest mało podatna na siły grawitacji i konsekwentnie alienuje się od społeczeństwa, przy jednoczesnym zachowaniu

19 Ch. Taylor, Źródłapodmiotowości. Narodziny tożsamościnowoczesnej, przeł. M. Gruszczyński, O. Latek, A. Lipszyc, A. Michalak, A. Rostkowska, M. Rychter, Ł. Sommer, PWN, Warszawa 2001, s. 53.

${ }^{20}$ Ch. Taylor, Etyka autentyczności, przeł. A. Pawelec, Wyd. Znak, Kraków 2002, s. 12. 
funkcji zarządzania nim, jednakowoż bez uwzględnienia jego interesów, oczekiwań i postulatów. Toteż wdrożenie idei w konkretną rzeczywistość polityczną odbywa się z pominięciem głosu otoczenia społecznego. Można się martwić o stabilność na dłuższą metę takiego ustroju, albowiem system przedstawicielski w takiej postaci, cieszy się coraz mniejszym zaufaniem społecznym i coraz częściej odmawia mu się legitymizacji społecznej wyrażanej przez udział w wyborach. Im powszechniejszy staje się taki styl uprawiania polityki, tym mniejsze stają się szanse na rzeczywiste rozwiązanie problemów i tym bardziej maleje zaufanie do zinstytucjonalizowanych kanałów politycznej artykulacji, które w społecznej percepcji coraz częściej uważane są za niewydolne. Następuje - zdaniem Taylora przesunięcie punktu ciężkości z ośrodków władzy opartych na modelu reprezentacyjnym, na władzę sądowniczą, której skład nie został określony na mocy aktu wyborczego. Skądinąd tendencja ta w naukach politycznych określana jest mianem trybunalizacji polityki. Decyzje sądowe mają na ogół postać „zwycięzca bierze wszystko”, co skutecznie ogranicza pole kompromisu i popularyzuje pogląd, że debata publiczna jest czymś jałowym. Artykulacja interesów staje się wówczas niemożliwa. Taylor konstatuje: „ten niezrównoważony system zarazem odzwierciedla, jak i mumifikuje rozdrobnienie. Jest on ucieleśnieniem ducha antagonistycznego: sukces obywatelski polega tu na umiejętności wyegzekwowania własnych praw, niezależnie od konsekwencji dla całości"21.

Innym problemem związanym z liberalną demokracją jest to, że mimo gwarancji równego dostępu do władzy, większość społeczeństwa pozbawiona jest realnego wpływu na procesy polityczne. Dzieje się tak, ponieważ przestrzeń polityczna została zawłaszczona przez elity, które kontrolują mechanizmy partyjne oraz środki masowego przekazu - słowem: ustalają reguły gry w taki sposób, by nie dopuścić do alternacji władzy i utrzymać w niezmienionym kształcie model oligarchiczny znany choćby $\mathrm{z}$ analiz Roberta Michelsa. Dlatego, jak zauważa MacIntyre, „wkroczenie w sferę liberalnej polityki w coraz większym stopniu wymaga zasobów finansowych, których dostarczyć może tylko kapitalizm korporacyjny, a zasoby te w zamian zapewniają uprzywilejowany dostęp do tych, którzy są w stanie wpływać na decyzje polityczne"22. Oczywistą tego konsekwencją jest usankcjonowanie przywileju wypowiedzi grupie rządzącej kosztem ograniczenia możliwości zabrania głosu masom wyborców, narażo-

${ }^{21}$ Ch. Taylor, Polityka liberalna, a sfera publiczna, [w:] Spoleczeństwo liberalne. Rozmowy w Castel Gandolfo, przeł. A. Kopacki, Wyd. Znak, Kraków 1996, s. 55.

22 A. MacIntyre, Etyka i polityka, oprac. A. Chmielewski, PWN, Warszawa 2009, s. 231. 
nych na coraz częstsze próby dewaloryzacji ich wkładu w funkcjonowanie wspólnoty politycznej. Dyskurs publiczny, zhegemonizowany przez elity polityczne, dostarcza jedynie ram organizacyjnych dla podejmowania decyzji o niewielkim znaczeniu dla porządku społecznego. Kwestie zaś najbardziej elementarne i zarazem fundamentalne dla istnienia wspólnoty politycznej są, jak uważa MacIntyre, poza zasięgiem ingerencji i kontroli większości społeczeństwa. System demokratyczny, w takim ujęciu, coraz bardziej zamienia swoje pierwotne znaczenie „rządy ludu” w groteskę, zaś przymiotnik „demokratyczny”, używany dla takiego sposobu sprawowania władzy, staje się z wolna nadużyciem terminologicznym.

Teoretycy komunitarianizmu, nie mając zaufania do ustroju demokratycznego w takiej postaci, w jakiej występuje w nowoczesnych państwach liberalnych, szukają miejsca dla dobrego życia nie tyle poza obrębem państwa, jak chcieliby anarchiści, nie tyle w opozycji do państwa, jak chciała tego opozycja antykomunistyczna w Polsce czy na Węgrzech, ile w obrębie państwa, jednak na jego lokalnym, albo lepiej powiedzieć, najniższym poziomie. Dezawuując wielką politykę, która stała się narzędziem elit, służącym realizacji wąsko pojmowanych interesów najbogatszych, komunitarianie optują za rewitalizacją idei społeczeństwa obywatelskiego. Bliżej jej do republikańskiego ducha społeczeństwa obywatelskiego, ale nieuprawnionym byłoby uważać obie koncepcje za tożsame, głównie $\mathrm{z}$ tego powodu, iż republikanizm kanalizuje energię obywatelską przede wszystkim na sprawach republiki, natomiast komunitarianizm koncentruje się na rozwoju wspólnot lokalnych i sąsiedzkich oraz zupełnie obca jest mu gloryfikacja państwa, jaka notorycznie pojawia się w rozważaniach filozofów republikańskich. Oryginalne podejście komunitarianizmu nie jest prostą mutacją republikanizmu również dlatego, że odrzuca charakterystyczne dla niego dogmaty, takie jak naturalność państwa i substancjalność dobra wspólnego. Odkładając na bok stare klisze teorii republikańskiej, uznając je w ten sposób za tyleż anachroniczne, co nieużyteczne, intelektualiści o orientacji komunitariańskiej, nie trwają w beznadziejnym przekonaniu, iż państwo jest tworem naturalnym, a jednocześnie wcześniejsze od swoich członków, albowiem takie przeświadczenie obalił już Hobbes, a decydujący cios zadał mu Locke. Nie trzeba podtrzymywać szkodliwego urojenia, że państwo ma charakter naturalny (w odróżnieniu od społeczeństwa), albowiem trudno wyobrazić sobie, żeby uznanie prymarności jednostki miało mu zaszkodzić. Ma za to pozytywne konsekwencje polityczne, ponieważ wyznacza granice dla interwencji państwa, a przez to nie pozwala na arbitralność 
władzy o dominującym rysie demokratycznym, monarchicznym czy jakimkolwiek innym.

W Taylorowskiej diagnozie stanu kultury i kondycji jednostek daje się słyszeć ton zatroskania o zanik heroicznego wymiaru życia, a tego rodzaju obawy sytuują go blisko intelektualistów tego formatu, co Alexis de Tocqueville, który pisał o „małych i pospolitych wzruszeniach”, Søren Kierkegaard, który wytykał nowoczesnym ludziom „brak pasji” oraz Fryderyk Nietzsche zarzucający im „żałosną wygodę”. Społeczne skutki takich zachowań widać wyraźnie, gdy uważnie przyjrzymy się zmianom, jakie zachodzą w nowoczesnych społeczeństwach, które stopniowo acz konsekwentnie odchodzą od formuły obywatelskiej na rzecz formuły społeczeństwa permisywnego czy konsumenckiego. Proponowana przez komunitarian idea społeczeństwa obywatelskiego ma odwrócić panujące tendencje. Ich zdaniem społeczeństwo polityczne musi być wpisane w istotę społeczeństwa obywatelskiego, ażeby można było odtworzyć klasyczny ideał obywatela wraz z jego kompetencjami politycznymi, lojalnością, zaangażowaniem, wszelako nie po to tylko, aby swoją troską otaczał sprawy państwa, ale przede wszystkim miał na uwadze dobro społeczności, w której żyje. Można to osiągnąć tylko w jeden sposób. Otóż, idzie o to, ażeby wzbudzić na nowo wiarę w obywatelach, iż każdy ich indywidualny wkład w sprawy lokalne ma znaczenie i jest pożądany. Od państwa natomiast oczekuje się, jak pisze Walzer, „decentralizacji [...] w taki sposób, by obywatele mieli więcej sposobności brania na siebie odpowiedzialności za (niektóre) jego działania”, „uspołecznienia gospodarki w taki sposób, by nastąpiła multiplikacja podmiotów rynkowych, zarówno społecznych, jak też prywatnych”, oraz "pluralizacji i oswojenia nacjonalizmu na wzór religii w taki sposób, by istniało wiele dróg urzeczywistnienia i utrwalenia historycznych tożsamości" ${ }^{23}$. Taylor natomiast dodałby, iż państwo powinno działać w oparciu o zasadę subsydiarności, która przewiduje, iż żadna rola społeczna nie powinna być osiągana przez instytucję większą niż taka, która jest do jej wykonania niezbędna.

Rewitalizacja lokalnych form wspólnotowych w wykonaniu komunitarian to spiritus movens szerszego i znacznie poważniejszego przedsięwzięcia, polegającego na przywróceniu klasycznego wymiaru obywatelskości, dzięki któremu możliwie byłoby zdynamizowanie życia na szczeblu lokalnym nie tylko na gruncie polityki, ale też w sferze społecz-

${ }^{23}$ M. Walzer, Spór o społeczeństwo obywatelskie, [w:] Ani książę, ani kupiec: obywatel: idea spoleczeństwa obywatelskiego w myśli wspótczesnej, wybór $i$ wstęp, J. Szacki, Wyd. Znak, Kraków 1997, s. 104. 
nej, zachowując w ten sposób dobre obyczaje oraz tradycje intelektualne i moralne ${ }^{24}$. Osiągnięcie projektowanych celów napotyka jednak na szereg trudności. Otóż, kiedy MacIntyre albo Taylor lansują wizję kolektywnej kooperacji w agonistycznej sferze polityki, mającej doprowadzić do uzgodnienia wolnego od wykluczeń konsensusu, milcząco lub otwarcie odwołują się do Habermasowskiego modelu deliberacji, zapominając jednak, że adaptując Habermasowską teorię, jednocześnie adaptują charakterystyczne dla niej słabości. Najpoważniejszą z nich jest to, że składa obietnice bez pokrycia w kontekście procesu negocjowania porozumienia, twierdząc, że jego punktem finalnym jest pełna zgoda w danej sprawie. Na ograniczenia konsensusu zwracał już uwagę Carl Schmitt. Według niego, każdy konsensus oparty jest na aktach wykluczenia, co oznacza, iż porozumienie w pełni inkluzywne jest po prostu iluzją ${ }^{25}$. Tak jak grecka polis nie potrafiła poradzić sobie z asymetrycznymi stosunkami politycznymi, z nierównością w dostępie do sfery polityki (i dodajmy, nie zawsze wina leżała po stronie samej polis), tak nie ma podstaw do przypuszczenia, by we wspólnocie afirmowanej przez MacIntyre'a i Taylora mogło być inaczej (nawet przyjmując założenie, że chodzi o stosunkowo niewielką społeczność). Tym bardziej, że w każdym dyskursie istnieje granica między tym, co jest do niego dopuszczone, a tym, co pozostaje na jego peryferiach i granica ta jest wyznaczana przez dominujący kanon przekonań zaangażowanych narracji, które systematycznie wykluczają tych, którzy nie podzielają ich stosunku do zasadniczych kwestii.

Konkludując, komunitariańska próba skorygowania w duchu wspólnotowym kompleksu ideologicznego i instytucjonalnego, zwłaszcza w warunkach pozornej bezalternatywności, kiedy niemal cały świat jednoczy się pod sztandarem liberalizmu i zdarza mu się coraz częściej przymykać oczy na jego defekty oraz koszty moralne i polityczne, jakie związane są z jego obowiązywaniem, jawi się jako oferta, co rzadko dziś się zdarza, subwersywna i niezwykle ciekawa, choć - jak starałem się wykazać - jest to próba skażona zbytnim pesymizmem w kwestii ewaluacji stanu dzisiejszej kultury, a zarazem przesadnym optymizmem w kwestii rozwiązania wszelkiego rodzaju bolączek przy użyciu praktyki wspólnotowej. Mimo to, ocena tego nurtu musi wypaść pozytywnie. Niemniej ani jego popularność, ani wpływowość nie są paralelne z jego niebagatelnym wkładem w ożywienie dyskusji nad ideami politycznymi. Wprawdzie jego

\footnotetext{
A. MacIntyre, Dziedzictwo cnoty, op. cit., s. 466.

C. Schmitt, Teologia polityczna i inne pisma, oprac. M. A. Cichocki, Wyd. Znak, Kraków 2000 , s. 230.
} 
oddziaływanie wykracza poza krąg elit intelektualnych, lecz nie tak szeroko, aby mówić o zmianie świadomości społecznej, aby dać wiarę zapewnieniom samych komunitarian o zreformowaniu w duchu wspólnotowym przestrzeni społecznej i kulturowej, które, póki co, są zmonopolizowane przez ideologię liberalną. I nawet kryzys gospodarczy sprzed dwóch lat nie będący przecież kolejnym potknięciem liberalizmu, lecz raczej głośnym upadkiem słonia w sklepie z porcelaną, nie spowodował porzucenia wiary w jego słuszność, lecz tylko kurczową, niezachwianą i jeszcze bardziej bezkrytyczną afirmację status quo. 


\section{Abstract}

The objective of this article is to examine how the idea of civic society has shaped in order to prove this concept is ambiguous with rich tradition of thought.observing modern theoretical and political discussions, it can be stated that the term of civic society occurs just and only in a modern sense, which means total and unjustified rejection of republican input on the development of this idea. The elimination of the thought of Aristotle, Cicero and their Middle Ages and later followers makes a theoretical construction of civic society very complicated and reduces its implementation value.

For to show how modern civic society referring to the classical political thought may look, the author presents output of communitarian philosophy, which worked out a novel approach to this problem. This approach varies from the liberal conception with the fact it speaks in favour of civic participation, raises the importance of civic virtues, and prefers 'positive' freedom to the 'negative' one.

Communitarianism in philosophy, like other schools of thought in contemporary political philosophy, can be defined by its response to A Theory of Justice by John Rawls, and also - in my opinion - to the political doctrine in statu nascendi.

Communitarianism emphasizes the need of balance the individual rights and interests with those ones of the community as a whole. MacIntyre, Taylor and Walzer argue that individual people are shaped by culture and values of their own communities. Some of communitarian theorists, for example Alisdair MacIntyre, condemn modern politics, especially liberalism and the institutions of a liberal state, as irredeemably fallen. In contrast, Charles Taylor and Michael Walzer offer competing communitarian responses to the contemporary challenge of pluralism, tolerance and freedom.

The original approach of communitarianism is not a simple mutation of republicanism, because it rejects its typical dogmas, such as: state and common wealth as natural creations. Whereas the tradition deriving from Aristotle has glorified state and focused the attention of the society on matters of republic, the philosophy of MacIntyre, Taylor and Walzer concentrates on cultivating local and neighbouring communities. 